\title{
ERRATUM
}

L. F. Capitán-Vallvey · E. Arroyo Guerrero

C. Berenguer Merelo · M. D. Fernández Ramos

\section{A test strip for chloride analysis in environmental water}

Published online: 25 February 2005

(C) Springer-Verlag 2005

\section{Anal Bioanal Chem (2004) 380:563-569}

Due to an unfortunate error the first surname of the authors was mistakenly abbreviated. The correct names are

L.F. Capitán-Vallvey, E. Arroyo Guerrero, C. Berenguer Merelo, M.D. Fernández Ramos

The online version of the original article can be found at http:/ dx.doi.org/10.1007/s00216-004-2735-6

L. F. Capitán-Vallvey $(\bowtie) \cdot$ E. Arroyo Guerrero

C. Berenguer Merelo · M. D. Fernández Ramos

Department of Analytical Chemistry,

University of Granada, Granada 18071, Spain

E-mail: lcapitan@ugr.es 